\title{
ANALYSIS OF CHANGES IN THE PHASE AND STRUCTURAL STATE OF AN ALUMINUM ALLOY 1933 SURFACE LAYER, MELTED BY A PULSED ELECTRON BEAM
}

\author{
D.E. Myla ${ }^{1,2}$, V.V. Bryukhovetsky ${ }^{1}$, V.V. Lytvynenko ${ }^{1}$, V.P. Poyda ${ }^{2}$, A.V. Poyda ${ }^{1}$, \\ V.F. Klepikov ${ }^{1}$, V.T. Uvarov ${ }^{3}$, Yu.F. Lonin ${ }^{3}$, A.G. Ponomarev ${ }^{3}$ \\ ${ }^{1}$ Institute of Electrophysics \& Radiating Technologies NAS of Ukraine, Kharkiv, Ukraine \\ E-mail: ntcefo@yahoo.com; \\ ${ }^{2}$ V.N. Karazin Kharkiv National University, Kharkiv, Ukraine \\ E-mail:postmaster@univer.kharkov.ua; \\ ${ }^{3}$ NSC “Kharkov Institute of Physics and Technology”, Kharkiv, Ukraine \\ E-mail: nsc@kipt.kharkov.ua
}

\begin{abstract}
The structural and phase changes in the surface layer of an aluminum alloy 1933 caused by the action of a relativistic pulsed electron beam are studied. The structural and phase state of this layer is determined by the impact action of the electron beam and by the kinetics of crystallization from the melt under ultrafast cooling. The impact of a pulsed electron beam is accompanied by the formation of a developed surface relief and the appearance of microcracks on it. The structure of the modified layer is nonequilibrium. X-ray diffraction studies and the results of energy dispersive X-ray microanalysis made it possible to determine that magnesium oxide inclusions are present in the remelted layer. $\mathrm{MgO}$ inclusions are generally uniformly distributed in the remelted layer. The maximum size of $\mathrm{MgO}$ inclusions does not exceed $1 \mu \mathrm{m}$. The causes and mechanisms of the formation of magnesium oxide during the action of a pulsed electron beam are discussed.
\end{abstract}

\section{INTRODUCTION}

Aluminum and its alloys as constructional materials are used in industry for a little over 100 years and are currently the most common materials after steel [1]. They are an indispensable constructional material not only in the aircraft industry, but also in the nuclear industry. In particular, seamless tubes for reactors are produced from aluminum alloys, as well as centrifuges for uranium enrichment. This was facilitated by a number of favorable properties of aluminum alloys, which are of particular importance in many areas of technology. In this case, the state of the surface layers of alloys, which play a decisive role in maintaining the operational characteristics of products in terms of their use, is of great importance. One of the methods for modifying and hardening of the surface layers of aluminum alloys is electrophysical radiation treatment by concentrated energy flows. The essence of this treatment is the transfer of energy from the radiation source to the surface being treated, which, as a result of powerful local energy exposure, acquires new properties. In this case, rapid heating to a high temperature (melting point) of the surface layer of the alloy occurs. This is followed by a very rapid cooling of this molten layer by heat removal to the bulk of the alloy, which remains practically cold. This causes the formation of significant concentrations of point defects in the material, and can also cause structural-phase changes in it. Structural-phase changes in solids due to irradiation can occur, in particular, quasicrystalline structures with unusual rotational symmetries can appear [2]. The structure and properties of the thus obtained remelted layers were studied previously in a number of works [3-9]. In this work, we studied the features of structural-phase changes in the surface layer of an industrial aluminum alloy 1933 irradiated with a pulsed electron beam.

\section{MATERIAL AND EXPERIMENTAL}

The studied alloy 1933 has such a chemical composition: $\mathrm{Al} ; 1.6 \ldots 2.2$ wt.\% $\mathrm{Mg} ; 0.8 \ldots 1.2 \mathrm{wt} \% \mathrm{Cu}$; 0.1 wt.\% Mn; $0.66 \ldots 0.15$ wt.\% Fe; 0.1 wt.\% Si; 6.35...7.2 wt.\% Zn; $0.03 \ldots 0.06$ wt.\% Ti; 0.05 wt.\% Cr; $0.10 \ldots 0.18$ wt.\% Zr; $0.0001 \ldots 0.02$ wt.\% Be [10].

Irradiation of alloys' plates was performed by a highcurrent pulsed beam of relativistic electrons at the MIG-1 accelerator in the NSC "KIPT" NAS of Ukraine [11]. The energy flux density at the target $\mathrm{W}$ was approximately $10^{9} \mathrm{~W} / \mathrm{cm}^{2}$ (beam energy $\mathrm{E} \sim 0.3 \mathrm{MeV}$, current $\mathrm{I} \sim 2000 \mathrm{~A}$, pulse duration $\tau_{\mathrm{i}} \sim 5 \cdot 10^{-6} \mathrm{~s}$, beam diameter $\mathrm{D} \sim 3 \mathrm{~cm}$ ).

Microstructure studies were performed using a light microscope MIM-6 with digital camera Pro-MicroScan. The average grain size $\langle d\rangle$ was determined from microphotographs using the random secant method.

Qualitative and quantitative X-ray analysis, determination of the crystal lattice parameters was performed on an X-ray diffractometer Shimadzu XRD6100.

Energy dispersive X-ray microanalysis of local microvolumes in the irradiated alloy layer was performed using a scanning electron microscope Tescan VEGA $3 \mathrm{LMH}$ with additional device for X-ray energy dispersive microanalysis "Bruker XFlash 5010".

\section{RESULTS AND DISCUSSION}

Fig. 1 shows a typical view of the initial grain microstructure fragment of alloy 1933. Earlier in [1214], it was found that the initial grain structure of the studied alloy 1933 is different-grained and polygonized. 
It contains colonies of recrystallized ultrafine grains with an average grain size $\langle d\rangle=(7 \pm 1) \mu \mathrm{m}$, as well as individual large grains with an average grain size $\langle d\rangle=(50 \pm 1) \mu \mathrm{m}$. The calculations showed that the average grain size in the original samples of alloy 1933 is $\langle d\rangle=(15 \pm 1) \mu \mathrm{m}$.

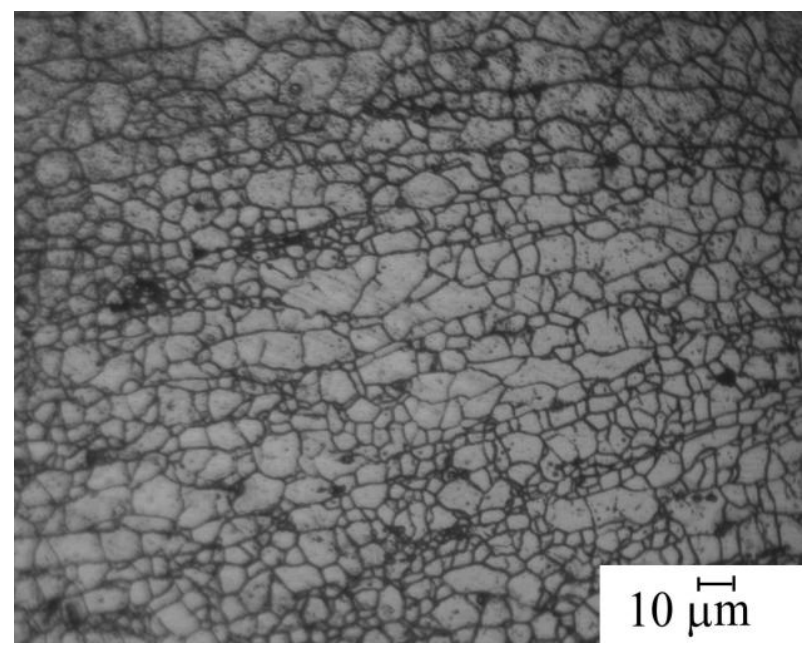

Fig. 1. General view of the initial grain microstructure of alloy 1933

Using energy dispersive X-ray microanalysis, it was found that magnesium, which is present in the alloy, is not uniformly distributed, and, apparently, is mainly a part of intermetallic inclusions [12-14].

In $\mathrm{Al}-\mathrm{Mg}-\mathrm{Cu}-\mathrm{Zn}$ system, zinc, magnesium and copper form eutectic phases with aluminum and with each other: $\mathrm{MgZn}_{2}$ ( $\eta$-phase), $\mathrm{Al}_{2} \mathrm{CuMg}$ (S-phase), $\mathrm{Mg}_{3} \mathrm{Zn}_{3} \mathrm{Al}_{2}$ (T-phase) [15]. As a result of diffractometric studies of the initial microstructure of alloy 1933, the presence of phases $\mathrm{MgZn}_{2}$ and $\mathrm{Mg}_{3} \mathrm{Zn}_{3} \mathrm{Al}_{2}$ was found, and the phase $\mathrm{Al}_{2} \mathrm{CuMg}$ was not revealed [13].

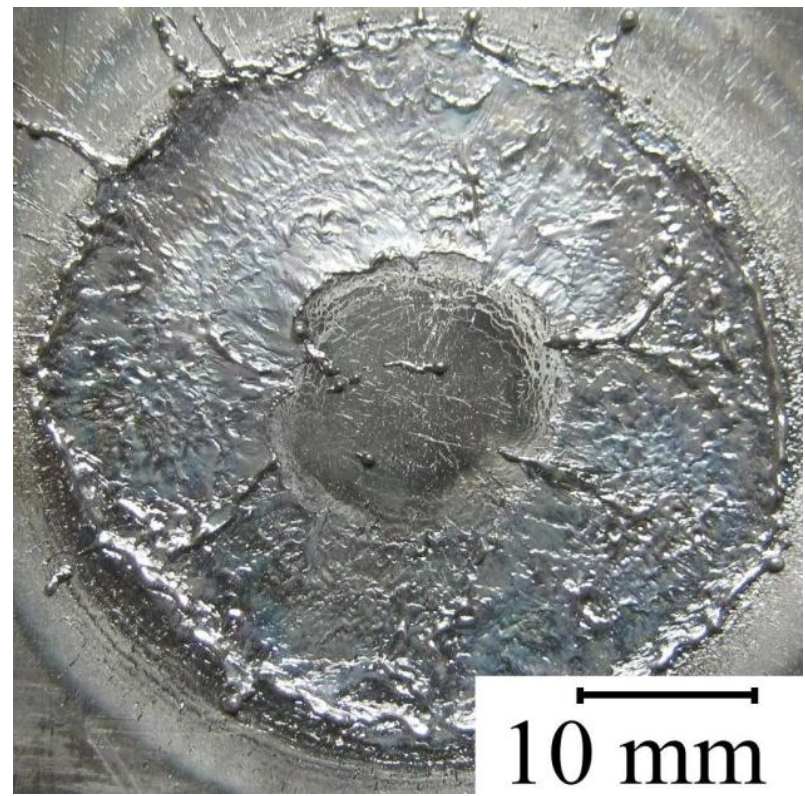

Fig. 2. General view of alloy 1933 plate surface irradiated by pulsed electron beam

Fig. 2 shows a general view of the plate surface made from cold-rolled alloy 1933 sheet, which was irradiated by a pulsed high-current relativistic electron beam. It is seen that the intense thermal heating of the plate created by the electron beam led to the melting of its surface layer.
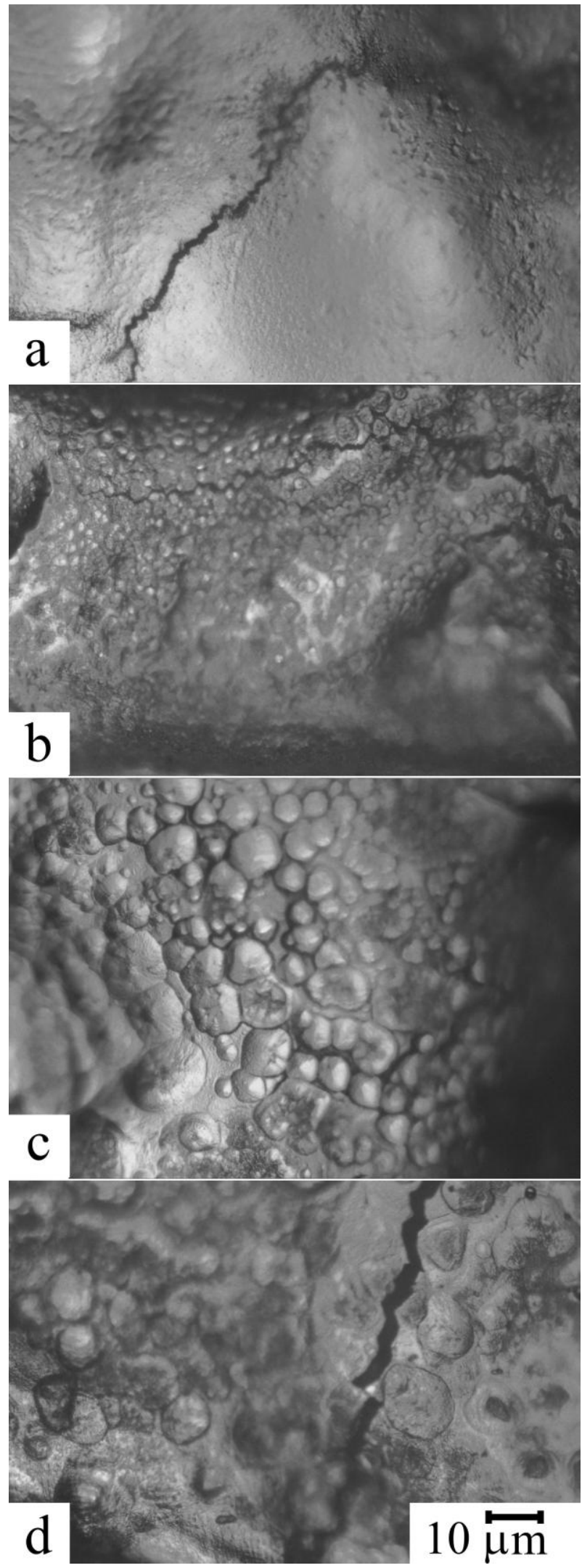

Fig. 3. Typical views of fragments of the irradiated alloy 1933 surface

Fig. 3 shows the fragments of 1933 alloy plate surface after irradiation by a pulsed relativistic electron 
beam. The sample in this figure is not polished and retains the usual surface relief, in which the history of crystallization of its surface is recorded. The impact of a pulsed electron beam is accompanied by the formation of a developed surface topography and the appearance of microcracks. Cracking of the surface layer is caused by the action of thermoelastic stresses during rapid crystallization. The formation of a drop-shaped relief is observed on individual fragments (see Fig. 3,c,d). Although, it should be noted that the distance between the cracks in the remelted layer of the 1933 alloy is much larger than in the previously studied AK4-1 alloy [8].

Fig. 4 shows the microstructure of the cross section in the zone of alloy processed by an electron beam. As can be seen from this figure, the thickness of the remelted surface layer is approximately $100 \mu \mathrm{m}$. It is known [16] that the solidification of the molten layer under the conditions of a large temperature gradient and high pressures leads to directed crystallization of the melt under nonequilibrium conditions, to obtain fine crystalline and amorphous structures. Thus, it is considered that treatment by a pulsed electron beam directly in the surface layers of the alloy contributes to the dispersion of the grain structure. The analysis of the microstructure type revealed that surface treatment by electron beam led to grain refinement. The structure of the modified layer, judging by the diffuse contrast of the grain boundaries, is nonequilibrium.

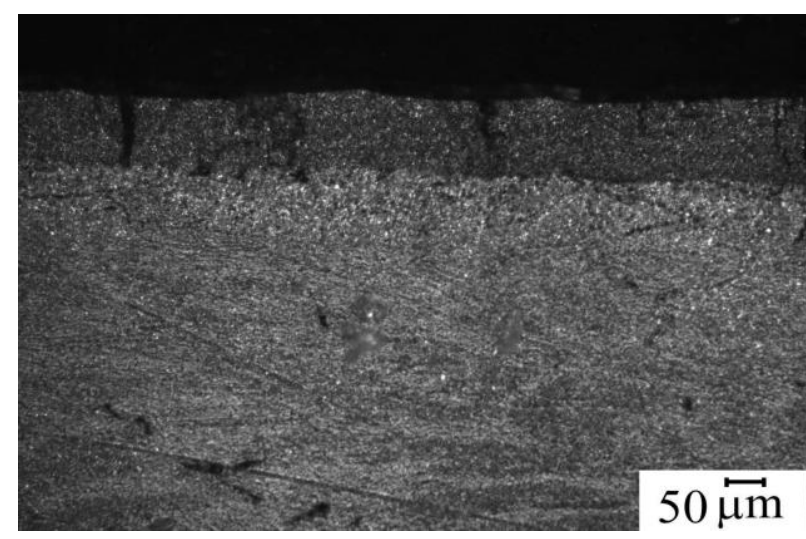

Fig. 4. Cross-sectional view of 1933 alloy in the electron beam processing zone

$\mathrm{X}$-ray studies were performed to study the phase composition of the surface remelted layer. The X-ray diffraction graph of the remelted layer of alloy 1933 is shown in Fig. 5. It is revealed that the intense diffraction peaks in the X-ray diffraction graph correspond to an aluminum-based solid solution $\left(\alpha_{\mathrm{Al}}\right.$-phase $)$ as well as magnesium oxide $(\mathrm{MgO})$. According to $\mathrm{X}$-ray studies, a significant amount (about 6.5 mass \%) of magnesium oxide is present in the remelted layer. The X-ray study does not show peaks corresponding to the $\eta$-phase $\left(\mathrm{MgZn}_{2}\right)$ and T-phase $\left(\mathrm{Mg}_{3} \mathrm{Zn}_{3} \mathrm{Al}_{2}\right)$, which were present in the initial state. Phase $\mathrm{Al}_{2} \mathrm{CuMg}$ was also not found by diffractometric studies in the remelted layer. This indicates that $\eta$-phase, $T$-phase, and S-phase, if even present in the remelted layer, only in a very small amount. At the same time, the crystal lattice parameter of the aluminum-based solid solution in the remelted layer is $0.4050 \mathrm{~nm}$, which corresponds to the lattice parameter of pure aluminum under the normal conditions.

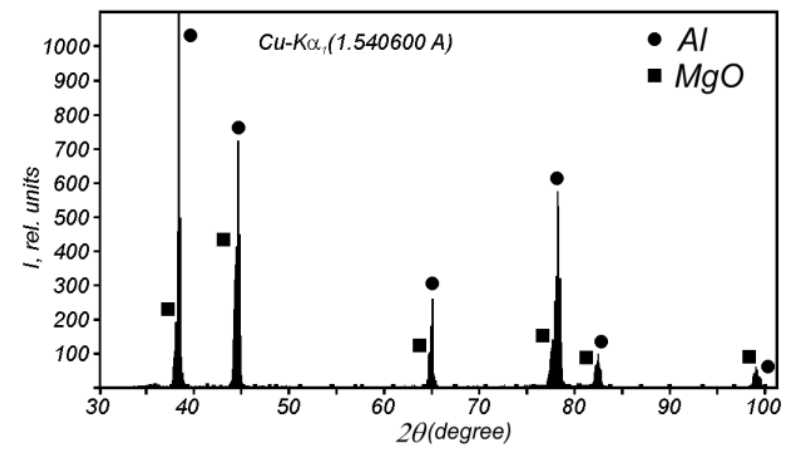

Fig. 5. X-ray diffraction graph of the remelted layer of the alloy 1933

To clarify the features of the magnesium oxide inclusions and secondary phases location in the remelted layer, an energy dispersive X-ray microanalysis of selected sections of the polished surface of the 1933 alloy remelted layer was performed. Fig. 6 shows such a fragment of modified 1933 alloy surface. The numbers $1,2,3$, and 4 mark the areas in which the chemical composition of these areas was determined using an energy dispersive X-ray microanalyzer. Table shows the chemical composition of the studied structural components in the remelted 1933 alloy layer. The structural component under spectrum No1 has a complex structure with a high oxygen content, which is probably due to the presence of fragments of either aluminum oxide or magnesium oxide.

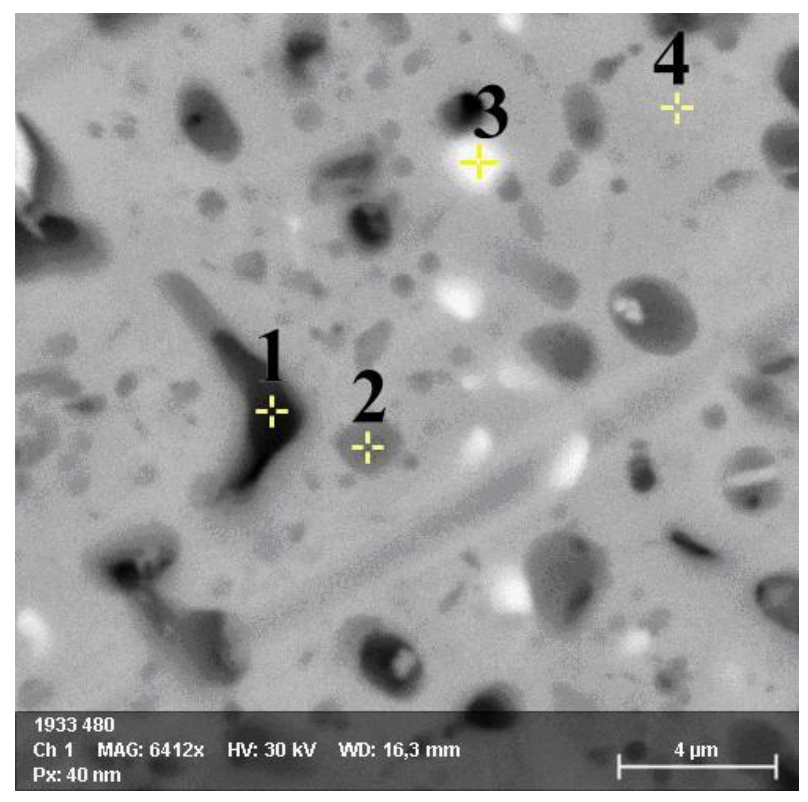

Fig. 6. A typical view of the surface area of alloy 1933 prepared for energy dispersive $X$-ray microanalysis.

Scanning electron microscopy

An analysis of the chemical composition of the structural component under spectrum No 2 suggests that the phase $\mathrm{Mg}_{3} \mathrm{Zn}_{3} \mathrm{Al}_{2}$ inclusions are most likely localized at this point. The inclusion of a light shade 
(spectrum No 3) has a very high oxygen concentration and also a high concentration of magnesium, which is more than 10 times higher than that for the average concentration in the alloy. The characteristic ratio of the mass fractions of oxygen and magnesium suggests that the inclusion of magnesium oxide is localized in this place. The chemical composition of the structural component under spectrum No 4 corresponds to $\alpha$-aluminum-based solid solution.

The chemical composition of the structural components in the 1933 alloy remelted layer

\begin{tabular}{|l|cc|}
\hline \multirow{2}{*}{$\begin{array}{l}\text { Chemical } \\
\text { element }\end{array}$} & \multicolumn{2}{|c|}{ Mass fraction, \% } \\
\cline { 2 - 3 } & Spectrum No 1 & Spectrum No 2 \\
\hline Aluminum & 90.13 & 70.83 \\
Magnesium & 1.69 & 12.45 \\
Oxygen & 3.42 & - \\
Copper & 0.68 & 1.23 \\
Zinc & 4.08 & 15.49 \\
\hline
\end{tabular}

\begin{tabular}{l|cc|}
\hline \multirow{2}{*}{$\begin{array}{l}\text { Chemical } \\
\text { element }\end{array}$} & \multicolumn{2}{|c|}{ Mass fraction, \% } \\
\cline { 2 - 3 } & Spectrum No 3 & Spectrum No 4 \\
\hline Aluminum & 59.56 & 92.73 \\
Magnesium & 18.94 & 1.39 \\
Oxygen & 19.93 & - \\
Copper & 0.47 & 0.98 \\
Zinc & 3.10 & 4.90 \\
\hline
\end{tabular}

Thus, diffractometric studies and the results of energy dispersive X-ray microanalysis suggest that magnesium oxide is present in the remelted layer. Fig. 7 shows the microstructure types of the remelted 1933 alloy layer.

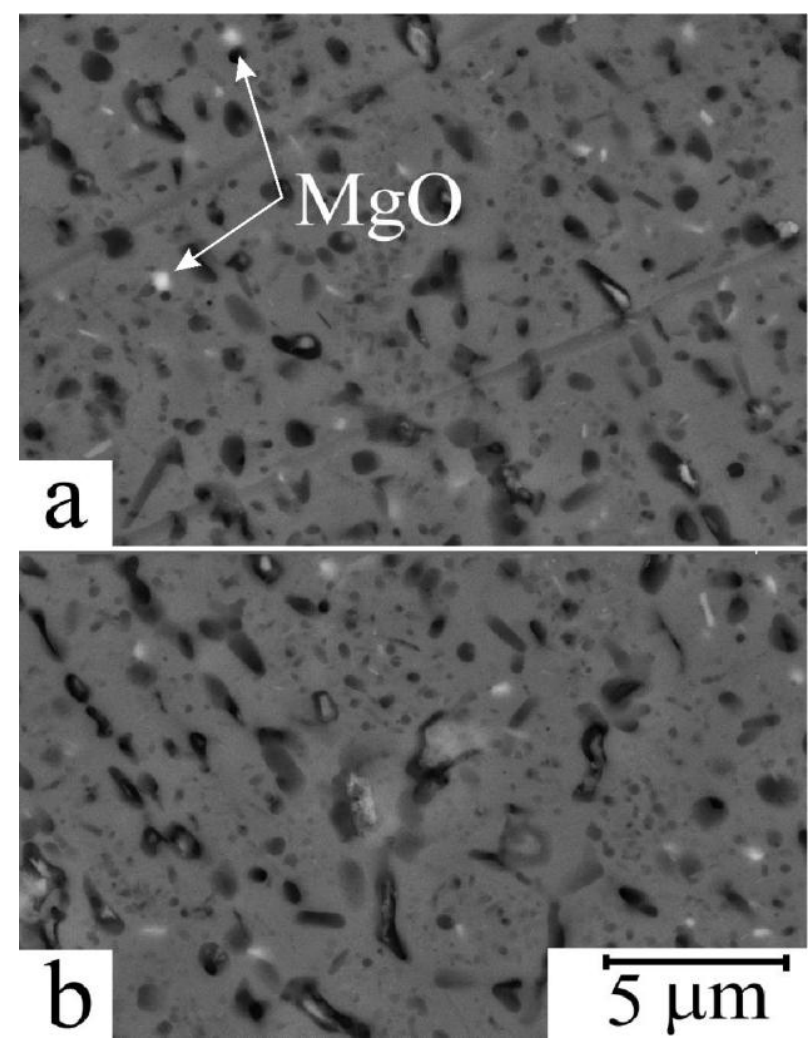

Fig. 7. The microstructure of the remelted 1933 alloy layer
Inclusions that have a light shade on the thin section are magnesium oxide. The sizes of $\mathrm{MgO}$ inclusions do not exceed $1 \mu \mathrm{m}$. They are uniformly distributed over the thin section, but there are places of a denser arrangement of inclusions. Metallographic analysis shows that approximately $3 \%$ of the volume fraction of magnesium oxide is present in the structure of the remelted layer.

The X-ray diffraction graph of the 1933 alloy remelted layer indicates that the conditions realized during pulsed irradiation lead to the formation of crystalline $\mathrm{MgO}$ particles. The lattice period of crystalline magnesium oxide under normal conditions is $0.4210 \mathrm{~nm}$ and its density is $3.58 \mathrm{~g} / \mathrm{cm}^{3}$. As shown by the results of diffractometric studies, $\mathrm{MgO}$ present in the composition of the remelted layer has a cubic facecentered lattice with a period of $0.4051 \mathrm{~nm}$, and its X-ray-graphic density is $4.027 \mathrm{~g} / \mathrm{cm}^{3}$. In this state, magnesium oxide can be obtained under conditions of high pressure [17]. Exactly pulsed high-current electron beams create these high pressures. At local beam energy concentrations exceeding $10^{7} \mathrm{~J} / \mathrm{cm}^{2}$, the pressure in the target can reach several megabars $[18,19]$.

To understand the mechanism of magnesium oxide formation, it is necessary to consider the dynamics and conditions of the pulsed irradiation process. The action of the pulsed beam is combined: the impactable, thermal and radiational $[18,19]$. Since the maximum energy absorption of the beam falls on the near-surface region of the plate, a microexplosion of the surface occurs, accompanied by a shock-plastic wave in the direction of the target and ejection of the material toward the beam [11]. Irradiation is performed inside the vacuum camera of the accelerator at a pressure of $10^{-4} \ldots 10^{-5}$ Torr. At this pressure, oxidation processes will occur due to the presence of oxygen in the residual vacuum medium. The oxidation of magnesium in the air is much more active than the oxidation of aluminum. Magnesium oxide forms more easily than $\mathrm{Al}_{2} \mathrm{O}_{3}$, due to the higher reactivity of magnesium than aluminum. Therefore, $\mathrm{MgO}$ is the starting material for oxidizing the melt of an aluminum alloy containing magnesium. The beam intensity, leading to surface melting of the plate and creating a shock wave, leads to crushing and spraying of inclusions of the secondary phases present in the initial state $[18,19]$. Magnesium is concentrated mainly in the form of intermetallic inclusions and eutectic layers, which at the time of irradiation are broken and instantly oxidized. Thus formed, magnesium oxide dispersoids precipitate in the crystallizing surface layer of the alloy. Thus, the structural and phase state of the modified remelted layer is determined by the impact of the electron beam, oxidation processes under conditions of residual vacuum, and crystallization from the melt under ultrafast cooling.

\section{CONCLUSIONS}

1. The impact of a pulsed electron beam on the plate of alloy 1933 leads to the melting of its surface layer. A drop-shaped relief with microcracks is formed on the surface of the remelted layer. 
2. X-ray diffraction studies showed that the magnesium oxide is present in the surface remelted layer. The $\mathrm{X}$-ray diffraction graph does not show peaks of the $\mathrm{MgZn}_{2}, \mathrm{Mg}_{3} \mathrm{Zn}_{3} \mathrm{Al}_{2}$, and $\mathrm{Al}_{2} \mathrm{CuMg}$ phases, which may be present in alloys of the Al-Mg-Cu-Zn system.

3 . The energy dispersive X-ray microanalysis of the selected sections of the polished surface of the 1933 alloy remelted layer also confirmed the presence of magnesium oxide in them.

4. To understand the mechanism of magnesium oxide formation, we analyzed the dynamics and conditions of the pulsed irradiation process. It is shown that the structural and phase state of the modified remelted layer is determined by the impact action of the electron beam, oxidation processes under conditions of a residual vacuum, and by the crystallization from the melt under ultrafast cooling.

\section{ACKNOWLEDGEMENT}

The research presented in this article was performed by financial support of the state budget program "Support for the development the priority areas of scientific researches" (Budget Financial Code 6541230).

\section{REFERENCES}

1. Handbook of Aluminum. Volume 1 - Physical Metallurgy and Processes / Ed. E. George, D. Totten, Scott MacKenzie, 2003, 1310 p.

2. A.I. Olemskoi, V.F. Klepikov. The theory of spatiotemporal graph in nonequilibrium systems // Phys. Rep. 2000, v. 338, N 6, p. 571-677.

3. A.G. Kobets, P.R. Horodek, Yu.F. Lonin, V.V. Lytvynenko, A.G. Ponomarev, O.A. Startsev, V.T. Uvarov. Melting effect on high current electron beam on aluminum alloy 1933 // Surface Engineering and Applied Electrochemistry. 2015, v. 51, N 5, p. 478 482.

4. V.V. Bryukhovetsky, V.P. Poyda, A.V. Poyda, V.F. Klepikov, D.E. Pedun, Yu.V. Kolomak. The influence of radiation factor on development of deformation processes in superplastic conditions // Problems of Atomic Science and Technology. 2012, N 5(81), p. 3-7.

5. V.T. Uvarov, V.V. Uvarov, V.N. Robuk, N.I. Bazaleev, A.G. Ponomarev, A.N. Nikitin, Yu.F. Lonin, T.I. Ivankina, V.F. Klepikov, V.V. Lytvynenko, S.Ye. Donets. Radiation acoustic control over the thermal parameter of construction materials irradiated by intense relativistic electron beam // Phys. of Part. and Nucl. Latter. 2014, v. 11, N 3, p. 274-281.

6. V.V. Bryukhovetskii, V.V. Litvinenko, V.F. Klepikov, R.I. Kuznetsova, V.P. Poida, V.F. Kivshik, and V.T. Uvarov. Effect of pulse electron irradiation on the parameters of duralumin superplasticity // Fiz. Khim. Obrab. Mater. 2002, N 4, p. 33-38 (in Russian).

7. V.V. Bryukhovetskij. On the origin of hightemperature superplasticity of a coarse-grained avialtype aluminum alloy // Fizika Metallov $i$ Metallovedenie. 2001, v.92, issue 1, p. 107-111 (in Russian).
8. V.V. Bryukhovetsky, A.V. Poyda, V.P. Poyda, D.E. Milaya. Superplastic deformation of the AK4-1 alloy with a surface layer melted by electron pulse beam // Problems of Atomic Science and Technology. 2019, N 2(120), p. 67-73.

9. V.P. Poyda, A.V. Poyda, V.V. Bryukhovetsky, Yu.V. Kolomak, D.Ye. Pedun, V.V. Litvinenko, V.T. Uvarov, A.G. Ponomar'ov, A.M. Kaafarani. The influence of pulsed electron irradiation on the formation of an ultrafine-grained structure and the parameters of the superplastic flow of aluminum alloys 1201, AMg-6 and $6111 / /$ Metallofizika i Noveyshiye Tekhnologii. 2011, v. 33, Special issue, p. 461-470 (in Russian).

10. I.N. Fridlyander. Aluminum alloys for aerospace engineering. Today, material knowledge of the 21st century. Kiev: "Naukova Dumka", 1998, 304 p.

11. V.F. Klepikov, Yu.F. Lonin, V.V. Lytvynenko, A.V. Pashenko, A.G. Ponomarev, V.V. Uvarov, V.T. Uvarov, V.I. Sheremet. The formation of strengthening coats by microsecond duration highcurrent relativistic electron beam // Problems of Atomic Science and Technology. Series "Nuclear Physics Investigations". 2008, N 5(50), p. 91-95.

12. V.P. Poida, D.E. Pedun, V.V. Bryukhovetskii, A.V. Poida, R.V. Sukhov, A.L. Samsonik, V.V. Litvinenko. Structural changes during superplastic deformation of high-strength alloy 1933 of the Al-Mg$\mathrm{Zn}-\mathrm{Cu}-\mathrm{Zr}$ system // Phys. Met. Metallogr. 2013, v. 114(9), p. 779-788.

13. V.V. Bryukhovetsky, A.V. Poyda, V.P. Poyda, D.E. Milaya. Superplastic behavior of 1933 aluminum alloy with bimodal structure at elevated temperatures // Problems of Atomic Science and Technology. 2018, N 2(114), p. 94-102.

14. A.V. Poyda, V.P. Poyda, V.V. Bryukhovetskyy, D.E. Myla, A.V. Zavdoveev. Influence of the grain size and of boundaries of grains structural state on parameters of superplasticity of an aluminium alloy Al$\mathrm{Zn}-\mathrm{Mg}-\mathrm{Cu}-\mathrm{Zr} / /$ Metallofizika i Noveishie Tekhnologii 2017, v. 39, N 10, p. 1345-1362 (in Russian).

15. V.I. Elagin, V.V. Zakharov, M.M. Drits. Structure and properties of alloys of the Al-Zn-Mg system. M.: "Metallurgy", 1982, 224 p.

16. Yu.K. Kovneristy, E.K. Osipov, E.A. Trofimov. Physical and chemical fundamentals of creating amorphous metal alloys. M.: "Nauka", 1983, 145 p.

17. S.D. Jacobsen, C.M. Holl, K.A. Adams, R.A. Fischer, E.S. Martin, C.R. Bina, J.F. Lin, V.B. Prakapenka, A. Kubo, P. Dera. Compression of single-crystal magnesium oxide to $118 \mathrm{GPa}$ and a ruby pressure gauge for helium pressure media // American Mineralogist. 2008, v. 93, p. 1823-1828; DOI: 10.2138/am.2008.2988.

18. O.V. Bogdankevich, A.A. Rukhadze. On the possibility of creating high pressure in a solid using a high-current electron beam // Letters to JETP. 1971, v. $13, \mathrm{~N} 9$, p. 517-519.

19. B.A. Demidov, M.V. Ivkin, V.A. Petrov, V.S. Uglov, V.D. Chejemov. Excitation of shock waves in thick targets by high-current REP // ZhTF. 1980, v. $50, \mathrm{~N} 10$, p. 2205-2208.

Статья поступила в редакиию 07.02.2020 2. 


\title{
АНАЛИЗ ИЗМЕНЕНИЙ ФАЗОВОГО И СТРУКТУРНОГО СОСТОЯНИЙ \\ ПОВЕРХНОСТНОГО СЛОЯ АЛЮМИНИЕВОГО СПЛАВА 1933, ПЕРЕПЛАВЛЕННОГО ИМПУЛЬСНЫМ ПУЧКОМ ЭЛЕКТРОНОВ
}

\section{Д.Е. Милая, В.В. Брюховецкий, В.В. Литвиненко, В.П. Пойда, А.В. Пойда, В.Ф. Клепиков,}

\author{
В.Т. Уваров, Ю.Ф. Лонин, А.Г. Пономарев
}

Изучены особенности структурных и фазовых изменений поверхностного слоя алюминиевого сплава 1933, вызванные воздействием релятивистского импульсного пучка электронов. Структурно-фазовое состояние данного слоя определяется ударным воздействием электронного пучка и кинетикой кристаллизации из расплава в условиях сверхбыстрого охлаждения. Воздействие импульсного пучка электронов сопровождается формированием развитого рельефа поверхности и появлением на ней микротрещин. Структура модифицированного слоя является неравновесной. Дифрактометрические исследования и результаты энергодисперсионного рентгеновского микроанализа позволили установить, что в переплавленном слое присутствуют включения оксида магния. Включения $\mathrm{MgO}$ в основном равномерно распределены в переплавленном слое. Максимальный размер включений $\mathrm{MgO}$ не превышает 1 мкм. Обсуждаются причины и механизмы образования оксида магния во время действия импульсного пучка электронов.

\section{АНАЛІЗ ЗМІН ФАЗОВОГО І СТРУКТУРНОГО СТАНІВ ПОВЕРХНЕВОГО ШАРУ АЛЮМІНІЕВОГО СПЛАВУ 1933, ПЕРЕПЛАВЛЕНОГО ІМПУЛЬСНИМ ПУЧКОМ ЕЛЕКТРОНІВ}

\section{Д.Є. Мила, В.В. Брюховецький, В.В. Литвиненко, В.П. Пойда, А.В. Пойда, В.Ф. Клепіков, В.Т. Уваров, Ю.Ф. Лонін, А.Г. Пономарьов}

Вивчено особливості структурних і фазових змін поверхневого шару алюмінієвого сплаву 1933 , викликані впливом релятивістського імпульсного пучка електронів. Структурно-фазовий стан даного шару визначається ударним впливом електронного пучка і кінетикою кристалізації 3 розплаву в умовах надшвидкого охолодження. Вплив імпульсного пучка електронів супроводжується формуванням розвинутого рельєфу поверхні i появою на ній мікротріщин. Структура модифікованого шару $\epsilon$ нерівноважною. Дифрактометричні дослідження i результати енергодисперсійного рентгенівського мікроаналізу дали змогу встановити, що в переплавленому шарі присутні включення оксиду магнію. Включення $\mathrm{MgO}$ в основному рівномірно розподілені в переплавлені шарі. Максимальний розмір включень $\mathrm{MgO}$ не перевищує 1 мкм. Обговорюються причини і механізми утворення оксиду магнію під час дії імпульсного пучка електронів. 